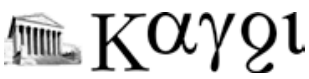

Kaygı Uludağ Üniversitesi Fen-Edebiyat Fakültesi Felsefe Dergisi

Uludağ University Faculty of Arts and Sciences Journal of Philosophy

Sayı 26 / Issue 26 | Bahar 2016 / Spring 2016

ISSN: 1303-4251

Research Article

Araştırma Makalesi

DOI: $10.20981 /$ kuufefd.49072

A. Kadir ÇÜÇEN

Prof. Dr. | Prof. Dr.

Uludag University, Faculty of Science and Letters, Department of Philosophy, Bursa-Turkey

Uludağ Üniversitesi, Fen-Edebiyat Fakültesi, Felsefe Bölümü, Bursa-Türkiye

kadir@uludag.edu.tr

\section{The Relation of the Self and External Reality}

\begin{abstract}
In order to explain the relation of the self and external reality for the purpose of demonstrating that the search for an ontological basis of the external world is not a meaningful one, it is necessary to explain, first of all, the concepts "self" and "external reality", and then go ahead to interrogate the relation of the self and external reality. In this paper, firstly the general understanding of the concept of self will be explained in terms of its epistemic nature and functions. Later, I will state my understanding of the concept of self and discuss its relation with the external world.
\end{abstract}

\section{Keywords}

Self, Reality, Subject, Object, World, Knower, Known. 


\section{The Self}

In the history of philosophy, the self is understood in various senses such as a mind (1); a soul (Plato, Aristotle); a subject (2); an absolute reason (Hegel); a God (3); a thinking thing (Descartes); an ego (4), human being (5); a Dasein (Heidegger) and so on.

In this paper, I will state my understanding of the concept of self in terms of its epistemic nature and functions. The self is an epistemological subject; by this, it is a knower as against being known. Therefore, the self is not passive, but active as knower of objects.

The function of the self is to know, to reflect, to think, etc; and the nature of the self derives these functions, the self is by nature a pure epistemic subject. In performing its functions, the self acts according to its own rules, it is free to act on its object such that it is capable of limiting its object rather than its object limiting itself.

The self is not an abstract and empty notion. Its existence is affirmed by its knowing and thinking, that is, its existence depends upon its functions. It exists not like a physical object neither, but in relation to its object of knowing. In other words, the self exists in the process of knowing its objects. Therefore, when the self is functionally active in thinking or knowing, then it manifests its existence.

In addition, the self or epistemic subject is neither dependent nor independent substance from the physical world. I mean here that the self is not an independent substance from the object, and it is not also an independent substance or object. (As I will explain later, object means what the self acts on, other than the self, or the other self, i.e. the external world.)

Opposite to Cartesian dualism, dualistic aspects of subject and object cannot be acceptable. Because if the subject is totally distinguished from the object, then the subject does know itself, but does not know the object. It even knows itself, but it does not express itself in a meaningful way.

My understanding of the self exists in the relation with the object or external world. The self is meaningful in its opposition. The self must recognize itself and the not-self in its connection to the not-self. The self has a reality and an existence as well as the not-self has. However, its reality is its activity on itself and on the not-self. Its activity, its nature, and its functions are inseparable from the self. Therefore, the self can be known by its activities and its attributes. Its attributes are "thought" "being rational", "knowing", "feeling", "perceiving", "hating", "loving", etc. I think that the self cannot be rendered by only one basic attribute.

\section{The External Reality}

Unlike the self who is a knower subject, the external reality is an epistemological object, i.e. it is an object which can be known by the self. Therefore, I will call the external object the not-self or an object known by the self. 
In the narrower sense, the external reality is the object of the physical world. In the broader sense, the external reality is more than the objects of the physical world. In this meaning of the external reality, it can be an abstract idea, or the object of immaterial culture, etc. Namely, the external reality which is the not-self can be understood as an object on which the self reflects.

By "external reality", I mean the objects of the self. The self has two kinds of objects: (1) Self-itself as an object; (2) the not-self as an object. In the first sense, the self takes itself as an object. I will call this kind of self-as-object as given directly to the self. The self knows its object primarily, directly, intuitively, absolutely, and completely, since the self reflects on itself directly.

The second type of object of the external reality is a secondary, indirect, descriptive, and sensuous knowledge. The former kind of knowledge can be called primary knowledge of the self; the latter is the relative knowledge of the self.

However, relative knowledge does not mean that there is primary knowledge of external reality. The knowledge of external reality is also a primary knowledge in terms of knowing the external reality itself. It is relative in terms of knowing the self itself. Here, I would like to refer to the Kantian separation of phenomena and noumena. I do not accept this separation, since there is no primary knowledge of noumena, as whatever we know is about phenomena or the external world is the primary knowledge of the external world.

External reality, as I said before, can be physical phenomena. All objects of the physical world are subject to the self. The self perceives the object of the physical world in the relation of its activity on the phenomena. External reality is not only perceptual and sensible objects, but also an object of culture, civilization, art, religion, philosophy, etc. Therefore, external reality for the self is the totality of outside of the self itself, i.e. the not-self and the other-self, or the otherness of the self.

\section{Self-Knowledge}

Self-knowledge is the higher aim of the philosophical inquiry. The knowledge of self itself depends on the relation in self, act, and the not-self. I assume that selfknowledge is possible because the self is a knowable subject. It is not the thing-in-itself in the Kantian sense. Self-knowledge depends upon not the knowledge of God but in the relation of self to its action and to the external reality.

\section{Who is Self?}

I hold that self is the active epistemic subject and the active epistemic subject is human being - Self is "I". As earlier noted, self is neither an abstraction nor an invisible being. Self is a reality, an active and thinking human being. Therefore, the task of philosophy of self turns to the task of philosophy of humans. The aim of that philosophy is to interrogate and demonstrate the nature of human beings. 
A human being can be known by what he does and what he has been rather than what he can be or what he ought to be. I believe that "what human is" is different from "what is the meaning of human". "What is the meaning of human" is a metaphysical and theological question. "What is human" is an epistemological question and can be answered in the external reality.

Self-as- human being is a process in time; it is not complete. Being human is an active process in the external world that understands, interprets and transforms both self and the external world. Being human is a process from potentiality to actuality. It changes and it is changed.

Self as human being can be stated in many relations:

a. Human being is a self-knower

b. Human being is a self in the natural world

c. Human being is a self in a social world

d. Human being is a self in a cultural world

e. Human being is a self in a historical world

f. Human being is a self in the creative world

g. Human being is a self as a self-realizer.

The self-as-human being shares in both finiteness and infiniteness that characterized existence. The self is partly finite in terms of inhabiting a physical body and partly infinite in terms of its activities in relation with the other-self. Self-as-human being finds itself here, there and now. In other words, my being here and now is not different to another self being there and now. I exist here and now like the other exists there and now. So I exist in time and space like the other exists.

Self-as-knower in the other six stages realizes and actualizes itself in the activity of man. Self is a relation with its activity to the external reality. What makes self-ashuman being different from animal, plants and physical objects? Human beings are tool makers and thinking or rational beings. They are rational animals. Here rational or thinking being means, I believe, that the human being realizes his activity and his actuality as a maker or doer. Therefore, human being as self and subject reflects on his activity and his thinking. Unlike human beings, animals, plants and physical objects cannot reflect on anything. They are known-beings whereas a human being is a knower.

\section{The relation of self and the external world}

The external world in the narrower sense is the physical world that is always there with or without the self. However, without self, there is no meaning of the phenomenal world. The self makes it meaningful. The self gets its meaningfulness in its relation to the phenomenal world. During its relation to the phenomenal world, the self creates its progressive and its activities in external reality. The self knows the external reality. There is no other reality which self is not able to know. External reality is restricted to the knowledge and the relation of the self. 
On the other hand, self does not create a new phenomenal world, but the self transforms the structure of phenomenal reality to another structure. There is no creation from ex-nihilo. The self is active, and external reality is passive in terms of epistemic requirements. The self is the subject, and the external reality is the object. The self acts on objects; i.e. the subject is related to its objects in the knowing relationship. The subject does not create its objects, but the subject realizes itself in the relation with its object.

\section{Some objections to this position}

1. The subject, in this position, is understood as being epistemological rather than ontological, since I suppose that the subject cannot do anything for the ontological foundation. The subject is not a creative God. Unlike creative beings, the subject understands, interprets and transforms the object. The subject is considered as an epistemological knower being.

2. What guarantees the existence of the self and the not-self in this position? The answer is nobody, because both exist in the relation of themselves. They complement each other. Without one of them, the other is an empty concept.

3. What is the ontological basis of external reality? Are external realities eternal? Physical objects as external realities are eternal. The phenomena were there; they are there, and they will be there. To look for a first cause in the phenomenal world is a logically and ontologically absurd argument. On the other hand, if the subject gives meaning to the physical world, there is no need to seek an uncaused being or a creator for the physical world. The objects of the immaterial culture or material culture are some kind of transformation of the activity of the self in external world.

In this sense, somehow the physical phenomena are in the universe; there is no first creation, but there is a transformation from one structure to another. Consequently, I believe that to look for an ontological basis of the external world is not a meaningful investigation; because the self finds itself and its object in this world, and it tries to understand both itself and the external world. 


\section{Ben ve Dış Dünya İlişkisi}

\section{Öz}

Ben ve diş dünya arasındaki ilişkiyi anlamak için sadece diş dünyanın ontolojik temelini gösterme amacı çok da anlamlı bir uğraş olmamaktadır. Çünkü öncelikle "Ben" ve "Dış Gerçeklik" kavramlarını belirgin biçimde tanımlama gerekliliği vardır. Sonra da bu iki kavram arasındaki ilişkinin sorgulanması yapılmalıdır. Bu makaelede ilkin "Ben" ve "Dış Gerçeklik" genel anlamıyla açıklandıktan sonar kendi görüşlerim doğrultusunda her iki kavram ve birbirleriyle olan ilişki ve etkileşimi açıklanacaktır. "Ben" ve "Dış Gerçeklik" işikisi çoğunlukla epitemolojik bağlamda ele alındığı için ikiciliğe giden felsefi kuramların ortaya çıkmasına yol açmıştır. Bu nedenle, "Ben" in epitemeik doğası ve özellikleri temelinde bilen öznenin dış dünaya yanı bilinen nesenye yönelmesi olarak alınan ilişki, çoğunlukla epitemolojik bir zeminde tartışılarak anlaşılmıştır. Sorgulanması gereken soru, “Acaba 'Ben' ile 'Dış Gerçkelik' arasındaki ilişkinin ontolojik temeli nedir? olmalıdır.

Bilen öznenin yalnızca bilme özelliklerinden yola çıkarak tanımlanması onu soyutlayarak bilinenden ayrı bir varlık alanına yerleştirilmesine neden olmaktadır. Diğer yandan bilinen nesne ve dış dünya, bilenden bağımsız bir varlık olarak izole edilmektedir. $\mathrm{Bu}$ makalenın amacı, bu düalist ayrıştırmayı tartışmak ve her ikisinin birlikteliğine varlıksal bir zemin bulmaya çalışmaktır.

\section{Anahtar Sözcükler}

Ben, D1ş Gerçeklik, Özne, Nesne, Dünya, Bilen, Bilinen. 


\section{Recommended Reading References}

Organ, Troy Wilson, Philosophy and the Self: East and West, Associated University Press, London 1987.

Olafson, Frederick A. What is Human Being? A Heideggerian View, University of California, San Diego, Cambridge University Press, 1995.

Steger, Eckar, E. The Many Dimensions of the Human Person, Peter Lang Publishing, New York, 2004.

Sihvola, Juha and Remes, Paulina (ed.), Ancient Philosophy of the Self, Springer, 2008.

Williams, Bernard, Problems of the Self, Cambridge University Press, 1973. 
